\title{
The Efficiency for the Three Industries of Provinces in China, Considering the Effects of Carbon Emission: An Application of the Parallel DEA Model
}

\author{
Feng Feng ${ }^{1} \&$ Jinlai Wang ${ }^{1}$ \\ ${ }^{1}$ School of Management, University of Science and Technology of China, Hefei, China \\ Correspondence: Jinlai Wang, School of Management, University of Science and Technology of China, Hefei, \\ China. Tel: 86-137-2111-2511. E-mail: wangj107@mail.ustc.edu.cn
}

\author{
Received: May 16, 2012 Accepted: June 9, 2012 Online Published: September 20, 2012 \\ doi:10.5539/ass.v8n12p28 URL: http://dx.doi.org/10.5539/ass.v8n12p28
}

\begin{abstract}
In this paper, a parallel DEA model was established and applied to evaluate the production performance of 29 provinces from China in 2009, considering the effects of $\mathrm{CO}_{2}$ emission. Meanwhile, a CCR DEA model was also used to evaluate the efficiencies for each industry, respectively. Our calculated results reveal that: a) the production efficiency for each province is relevant to the economic development level; $b$ ) the efficiencies are of great differences between regions, i.e., the eastern coastal area is more highly efficiency than the western interior area significantly; c) the efficiency of the primary industry are higher than those of the secondary industry and tertiary industry in average, and the score for tertiary industry efficiency is of the least influences of regions.
\end{abstract}

Keywords: parallel DEA model, productive efficiency, industries, carbon emission

\section{Introduction}

In the last few decades, the issue of climate change has become a more and more severe challenge internationally. Thus, a global agreement to develop the low-carbon economy has been reached. It is necessary to reduce the emission of greenhouse gases, especially the carbon dioxide $\left(\mathrm{CO}_{2}\right)$. Nowadays, China's economy is rapidly developing, that has already become the second largest economy in the world. China has become the second largest $\mathrm{CO}_{2}$-emitting country, and the amount of emmited- $\mathrm{CO}_{2}$ would increase sharply with the processes of China's industrialization and urbanization. To coordinate the relationship between carbon emission reduction and economy development is a very important issue to the government. Due to the vast territory of China, the structures of industries and energy distribution are of great difference with regions, so as to the level of economic development. So it is of great practical significance to make proper energy and environment policies which could promote the development of local economy. This study is to evaluate the efficiency of Chinese provincial region production system, which is considered the industries and the $\mathrm{CO}_{2}$ emission.

\section{Literature Review}

Previous researches have demonstrated that the economic growth is relevant with the environmental quality. Nemat (1992) has suggested that the income have high correlation with the environmental indicators under the study of relationships between environmental indicators and economy growth and found. Meanwhile, a U-shape environmental Kuznets curve is also found, which showed a trend that the per capita GDP increase first and then decrease with the increase of the pollution emissions (Grossman and Krueger, 2001). As more and more attentions have been paid to the carbon emission, the relationships between economy growth and carbon emission has become a research hot spot. A number of evaluation indicators have been proposed, for instance, the energy intensity (Martin, J.M,1988;), the Carbonization Index (A. Grubler,), the carbon emissions intensity (Ang B W., 1999), which are mainly used to evaluate the relationships between carbon emission, energy consumption and the national production. However, these indicators are all single-factor evaluation indicators, which only consider the proportional relationship between variables without evaluating interactions between those factors. Thus, in order to compensate for the limitations of the single-factor evaluation method, total factor evaluation methods have been widely applied, of which the DEA method is a typical one.

The DEA method is proposed by Charnes et al. (1978) to evaluate the relative efficiency of decision making units with multiple input and output. Because of the practicality and convenience, the DEA method has been 
widely applied in various subjects. To assess the environment performance in certain sector or measure the efficiency for productivity in regard to the environmental constraints, the environmental DEA method was suggested. Fare et al (1989), Sancho et al. (2000) used the environmental DEA method to evaluate the paper and glass manufactures in United States and Spain respectively. In recent years, the method is used to evaluate the efficiency for macro-economic field (e.g. Zhou et al., 2002; Guo et al., 2010; Liu et al., 2011). Previous studies usually compared the performance between provinces, but rarely took account the industrial structure to measure the production efficiency with carbon emission constraints. In this study, we introduce the industrial structure of China's provinces to measure the production efficiency with the carbon emission effects.

\section{Methodology}

A parallel DEA model with independent subsystem was established.

\subsection{Indicators}

According to the macroeconomics production function, every production unit consumes stock capital, labor force and yields GDP. While the study considered the influence by the $\mathrm{CO}_{2}$ emission, while the most important source for carbon emission is the consumption of energy. So the indicator involves $\mathrm{CO}_{2}$ emission and energy consumption. So the indicators selected for this study are listed in the following Table 1.

Table 1. Indicators related in the efficiency measuring

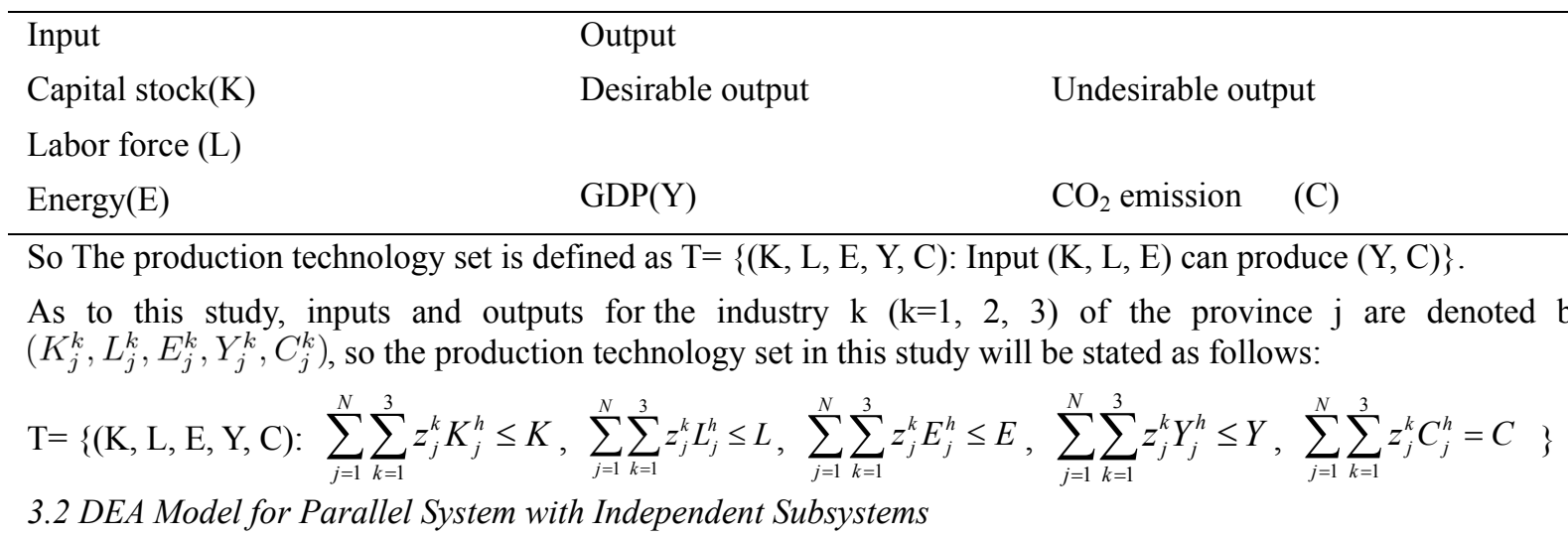

The entire national production sectors can be divided into three parts: primary industry, secondary industry and the tertiary industry. The three industries are independent to each other, so they can be regarded as the subsystems of the entire production system. The structure of this kind of system is shown in the figure 1.

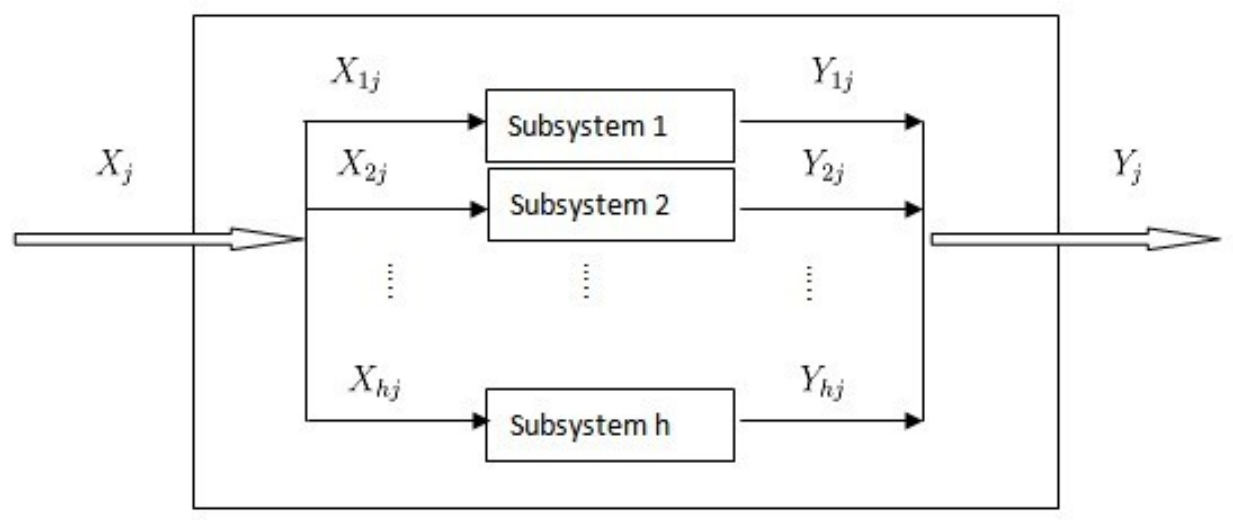

Figure 1. Structure for parallel system with independent subsystems

Let $X_{j}^{h}, Y_{j}^{h}, C_{j}^{h}$ state the vectors of the input, desirable output, and undesirable output for province j's industry h respectively. As to this study, $X_{j}^{h}=\left(K_{j}^{h}, L_{j}^{h}, E_{j}^{h}\right)$. As the undesirable output have the character to the input indicators. We treat the undesirable output as the input which is following the former research. Accordingly, in the case of constant returns to scale, the model for efficiency measuring to the system is as follows: 


$$
\begin{aligned}
& M A X \frac{\sum_{k=1}^{h} u^{k} Y_{d}^{k}}{\sum_{k=1}^{h} v^{k} X_{d}^{k}+\sum_{k=1}^{h} v^{\prime k} C_{d}^{k}} \\
& \text { s.t. } \quad \frac{\sum_{k=1}^{h} u^{k} Y_{j}^{k}}{\sum_{k=1}^{h} v^{k} X_{j}^{k}+\sum_{k=1}^{h} v^{\prime k} C_{j}^{k}} \leq 1 \\
& u^{\mathrm{k}}, \mathrm{v}^{\mathrm{k}}, \mathrm{v}^{\mathrm{k}} \geq 0, \mathrm{j}=1,2, \ldots, \mathrm{n}, \mathrm{k}=1,2, \ldots, \mathrm{h}
\end{aligned}
$$

Define $\mathrm{uk}^{*}, \mathrm{vk}^{*}, \mathrm{v}^{\prime} \mathrm{k}^{*}$ as the optimal solution of (1), thus, the efficiency for DMU-d is as follow:

$$
E F F_{d}=\frac{\sum_{k=1}^{h} u^{k^{*}} Y_{d}^{k}}{\sum_{k=1}^{h} v^{k^{*}} X_{d}^{k}+\sum_{k=1}^{h} v^{k^{*}} C_{d}^{k}}
$$

Considering the relative efficiency between the same industry of provinces, the tradition CCR-DEA model could be employed. Thus, the efficiency of industry $\mathrm{k}(\mathrm{k}=1,2,3$, stands for primary industry, secondary industry and tertiary industry) can be evaluate in this way:

$$
\begin{array}{cc} 
& M A X \frac{u^{k} Y_{d}^{k}}{v^{k} X_{d}^{k}+v^{\prime k} C_{d}^{k}} \\
\text { s.t. } \quad u^{k} Y_{j}^{h}-v^{k} X_{j}^{k}-v^{\prime k} C_{j}^{k} \leq 0 \\
\mathrm{u}^{\mathrm{k}}, \mathrm{v}^{\mathrm{k}}, \mathrm{v}^{, \mathrm{k}} \geq 0, \mathrm{j}=1,2, \ldots, \mathrm{n}, \mathrm{k}=1,2, \ldots, \mathrm{h}
\end{array}
$$

Supposed $u^{k^{*}}, v^{k^{*}}, v^{k^{*}}$ to be the optimal solutions to (3), the efficiency for the industry $\mathrm{k}$ of provinces $\mathrm{d}$ is:

$$
\begin{aligned}
E F F_{d}^{k} & =\frac{u^{k^{*}} Y_{d}^{k}}{v^{k^{*}} X_{d}^{k}+v^{k^{*}} C_{d}^{k}} \\
k & =1,2, \ldots, h
\end{aligned}
$$

According to the former study of Yang, the DEA efficiency for DMUs with independent subsystems are named YMK-DEA efficiency and the YMK efficiency for the system are defined by the most efficient subsystem. Thus, to this study, we have:

$$
E F F_{d}=\max _{k=1,2, \ldots h}\left\{E F F_{d}^{k}\right\}
$$

Overall, we could measuring the efficiency for each industry of every provinces in the case of constant returns to scale, then get the YMK-DEA efficiency for each province following the rule (5).

\section{Data}

The empirical study covers 29 provinces from Chinese mainland, excluding Hainan and Tibet owing to the data loss. Each province consumes capital stock (K), Labor force (L) and Energy (E) to yield GDP (Y) with the undesirable $\mathrm{CO} 2$ emission $(\mathrm{C})$. The data source and processing are as follows:

a) Capital stock

The capital stock for industries at provincial level cannot be got directly from the official statistics data. So we approximately calculated the capital stock for every province's industries. First, perpetual inventory method was 
used to calculate the stock for provinces in 2009 , then we divided the capital stock into three parts according to the proportion of each industrial investment to total investment.

b) Labor force

This study take the average employment in each province in 2009 as the labor force indicator.

c) Energy

Energy consumption for industries at provincial level are given in the energy yearbook for china in the form of physical quantity. The date should be transformed into standard quantity according to the calorific value.

d) GDP

The output of the three industries of the province can directly be got from the statistical yearbook for China and the yearbook for each province.

e) $\mathrm{CO}_{2}$ emission

The amount of $\mathrm{CO}_{2}$ emission was calculated from the fossil fuel consumption by the method recommended by IPCC. But the $\mathrm{CO}_{2}$ arise in production sectors are not taken into account in this study.

Table 2. The unit and data sources

\begin{tabular}{|c|c|c|c|c|c|c|}
\hline \multicolumn{2}{|l|}{ Indicator } & $\begin{array}{l}\text { Variable } \\
\text { symbol }\end{array}$ & \multicolumn{2}{|l|}{ Unit } & \multicolumn{2}{|l|}{ Data sources } \\
\hline \multicolumn{2}{|l|}{ Capital stock } & K & \multicolumn{2}{|c|}{$\begin{array}{l}\text { Billion yuan (measured in } \\
1952 \text { prices) }\end{array}$} & \multicolumn{2}{|c|}{$\begin{array}{l}\text { China statistical yearbook 2010, National } \\
\text { Bureau of Statistics. }\end{array}$} \\
\hline \multicolumn{2}{|l|}{ Labor force } & $\mathrm{L}$ & \multicolumn{2}{|c|}{ Million workers } & \multicolumn{2}{|c|}{$\begin{array}{l}\text { China statistical yearbook 2010, National } \\
\text { Bureau of Statistics. }\end{array}$} \\
\hline \multicolumn{2}{|l|}{$\begin{array}{l}\text { Primary } \\
\text { consumption }\end{array}$} & E & $\begin{array}{l}\text { Million ton } \\
\text { equivalent }(n\end{array}$ & of coal & \multicolumn{2}{|c|}{$\begin{array}{l}\text { China Energy statistical yearbook, } 2010 . \\
\text { National Bureau of Statistics. }\end{array}$} \\
\hline \multicolumn{2}{|l|}{ GDP } & $\mathrm{Y}$ & $\begin{array}{l}\text { Billion yuan } \\
2007 \text { prices) }\end{array}$ & asured in & \multicolumn{2}{|c|}{$\begin{array}{l}\text { China statistical yearbook 2010, National } \\
\text { Bureau of Statistics. }\end{array}$} \\
\hline \multicolumn{2}{|l|}{$\mathrm{CO}_{2}$ emission } & $\mathrm{C}$ & Million tons & & \multicolumn{2}{|c|}{$\begin{array}{l}\text { China Energy statistical yearbook, } 2010 . \\
\text { National Bureau of Statistics. }\end{array}$} \\
\hline Indicator & Industry & Capital stock & Labor force & energy & GDP & $\mathrm{CO} 2$ \\
\hline \multirow{3}{*}{ Mean } & I & 37.57 & 10.39 & 285.62 & 950.40 & 393.47 \\
\hline & II & 574.18 & 7.23 & 8728.06 & 4934.19 & 15762.14 \\
\hline & III & 709.28 & 8.62 & 1983.44 & 4120.64 & 2650.27 \\
\hline \multirow{3}{*}{ SD } & I & 25.80 & 7.48 & 174.09 & 687.80 & 227.34 \\
\hline & II & 511.55 & 6.64 & 6322.60 & 4696.82 & 10533.98 \\
\hline & III & 512.49 & 5.60 & 2905.00 & 3922.82 & 2011.23 \\
\hline \multirow{3}{*}{ Max } & I & $\begin{array}{c}102.22 \\
\text { (He'nan) }\end{array}$ & $\begin{array}{c}27.65 \\
\text { (He'nan) }\end{array}$ & $\begin{array}{c}678.11 \\
\text { (Hunan) }\end{array}$ & $\begin{array}{l}2567.67 \\
\text { (Shandong) }\end{array}$ & $\begin{array}{c}767.89 \\
\text { (Hunan) }\end{array}$ \\
\hline & II & $\begin{array}{c}1784.50 \\
\text { (Shandong) }\end{array}$ & $\begin{array}{c}22.12 \\
\text { (Guangdong) }\end{array}$ & $\begin{array}{l}24806.46 \\
\text { (Shandong) }\end{array}$ & $\begin{array}{c}16034.92 \\
\text { (Guangdong) }\end{array}$ & $\begin{array}{c}43257.78 \\
\text { (Shandong) }\end{array}$ \\
\hline & III & $\begin{array}{c}1785.04 \\
\text { (Zhejiang) }\end{array}$ & $\begin{array}{c}19.83 \\
\text { (Shandong) }\end{array}$ & $\begin{array}{c}12002.58 \\
\text { (Hubei) }\end{array}$ & $\begin{array}{c}14906.09 \\
\text { (Guangdong) }\end{array}$ & $\begin{array}{c}8030.21 \\
\text { (Shandong) }\end{array}$ \\
\hline \multirow{3}{*}{ Min } & I & $\begin{array}{c}4.25 \\
\text { (Shanghai) }\end{array}$ & $\begin{array}{c}0.49 \\
\text { (Shanghai) }\end{array}$ & $\begin{array}{c}17.53 \\
\text { (Qinghai) }\end{array}$ & $\begin{array}{c}85.95 \\
\text { (Qinghai) }\end{array}$ & $\begin{array}{c}28.96 \\
\text { (Qinghai) }\end{array}$ \\
\hline & II & $\begin{array}{c}84.70 \\
\text { (Qinghai) }\end{array}$ & $\begin{array}{c}0.70 \\
\text { (Qinghai) }\end{array}$ & $\begin{array}{c}840.26 \\
\text { (Qinghai) }\end{array}$ & $\begin{array}{c}460.40 \\
\text { (Qinghai) }\end{array}$ & $\begin{array}{l}2072.19 \\
\text { (Qinghai) }\end{array}$ \\
\hline & III & $\begin{array}{c}72.79 \\
\text { (Qinghai) }\end{array}$ & $\begin{array}{c}1.12 \\
\text { (Qinghai) }\end{array}$ & $\begin{array}{c}164.37 \\
\text { (Qinghai) }\end{array}$ & $\begin{array}{c}318.93 \\
\text { (Qinghai) }\end{array}$ & $\begin{array}{c}450.54 \\
\text { (Qinghai) }\end{array}$ \\
\hline
\end{tabular}




\section{Result}

\subsection{Result for Three Industries Respectively}

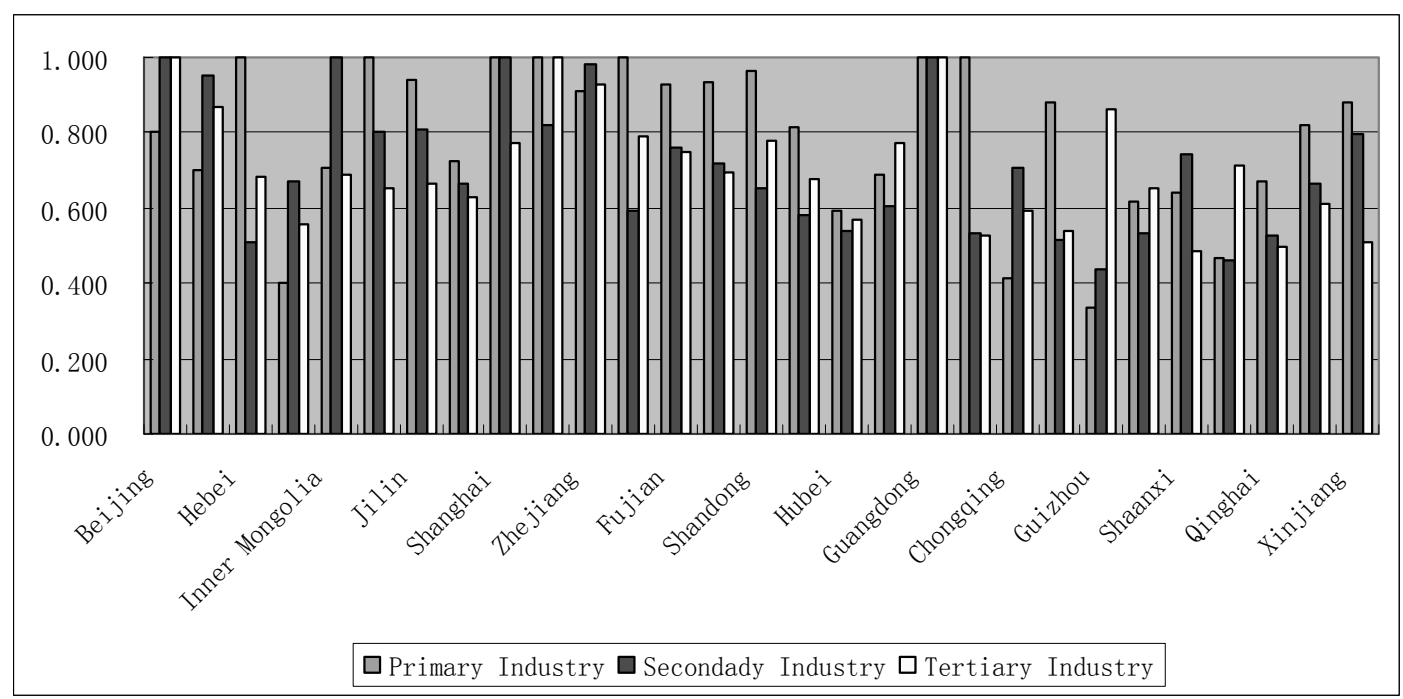

Figure 2. Efficiency for industries of provinces of China

As to the primary industry, the average score for the efficiency is $\sim 0.8$. Hebei, Liaoning, Shanghai, Jiangsu, Guangdong and Guangxi have a full score of 1 . These provinces are DEA efficient while other provinces are not as good as the former six provinces in the primary industry production performance, especially Shanxi and Chongqing which score less than 0.5 . Obviously, the provinces with higher scores are in China eastern coastal area of China, where the economic development is the best.

The efficiency score for the secondary industry are at the average of 0.709 , which is somewhat lower than that of the primary industry. Beijing, Inner Mongolia, Shanghai and Guangzhou are in the production frontier, which have a score of 1, Liaoning, Tianjin, Jilin, Jiangsu and Zhejiang are areas also with relatively high DEA efficiency. But the production efficiency for Hebei, Hubei and Qinghai are obviously lower than others. There is a large improvement room for the three provinces. As is similar to the primary industry, the areas with higher efficiency are also those more developed provinces.

The efficiency for tertiary industry presents the same case as the former two industries, i.e., the more developed the provinces are (e.g. Beijing, Jiangsu, Guangdong etc.), the higher efficiency they got. Meanwhile, Shanxi, Hubei, Guangxi and Shaanxi is less efficient. Especially, Shaanxi province scores only 49\%, which is the only province get a score less than $50 \%$.

Table 4. Average production efficiency of China's eight economic regions in 2009

\begin{tabular}{llll}
\hline & $\begin{array}{l}\text { Primary } \\
\text { Industry }\end{array}$ & $\begin{array}{l}\text { Secondary } \\
\text { Industry }\end{array}$ & $\begin{array}{l}\text { Tertiary } \\
\text { Industry }\end{array}$ \\
\hline Northern coastal area(NC) & 0.867 & 0.778 & 0.834 \\
Eastern coastal area(EC) & 0.969 & 0.934 & 0.902 \\
Southern coastal area(SC) & 0.965 & 0.881 & 0.875 \\
Northeast China(NE) & 0.888 & 0.758 & 0.647 \\
Middle Yellow River region(MY) & 0.641 & 0.748 & 0.604 \\
Middle Yangtze River region(MYT) & 0.805 & 0.614 & 0.706 \\
Southwest area of China(SW) & 0.649 & 0.545 & 0.634 \\
Northwest area of China(NW) & 0.710 & 0.612 & 0.584 \\
\hline
\end{tabular}

As listed in Table 4, provinces in eastern coastal area perform the best efficiency, which is the most developed area in China. The efficiency for three industries there are all over 0.9. Afterwards, provinces which are located in the northern and southern coastal areas usually got a score of over 0.8. Provinces in the western inland area score lower than the leading area by $1 / 3$, the disparity of the secondary industry efficiency between the Southeast 
China and eastern coastal area reaches $40 \%$. Overall, the efficiency for each industry gradually reduces from east to west, also with a trend from the coastal area to inland area.

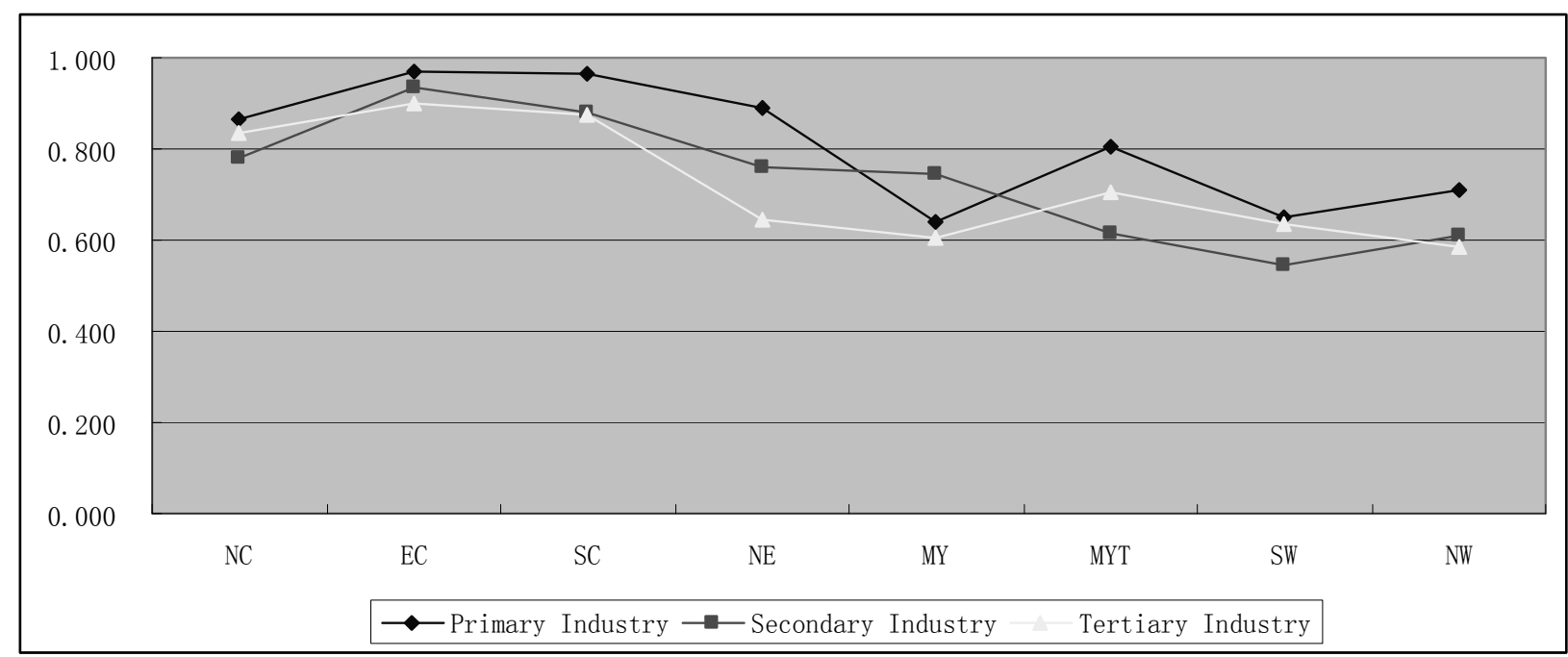

Figure 3. Production efficiency for industries for economic areas in China

Comparing the efficiencies of the three industries, we found that the efficiency of the primary industry is the highest while the secondary and tertiary industries are lower (fig.3). The area which has higher efficiency of primary industry also gets higher score in the other industries. Of the three industries, the tertiary gives the smallest changing amplitude. This could be a result of the latest development of the tertiary industry. Thus, the first-mover advantage of the early-developed area might not be so obvious. Meanwhile, the tertiary industry usually shows less restrictive of locations and resources. On the contrast, different locations, climate conditions and resources could bring in obvious influences to the primary and secondary industries. In this way, unlike the primary and secondary industries, the tertiary industry usually shows more stable efficiency

\subsection{Production Efficiency for Provinces}

Based on our suggested model, the productive efficiency of provinces in china which considering the carbon emission could calculated. The results are listed in table.5.

Table 5. The YMK efficiency of provinces in China in 2009

\begin{tabular}{|c|c|c|c|c|c|c|c|c|c|}
\hline Provinces & $\begin{array}{c}\text { Primary } \\
\text { industries }\end{array}$ & $\begin{array}{c}\text { Secondary } \\
\text { instries }\end{array}$ & $\begin{array}{l}\text { Tertiary } \\
\text { industries }\end{array}$ & YMK & Provinces & $\begin{array}{l}\text { Primary } \\
\text { industries }\end{array}$ & $\begin{array}{l}\text { Secondary } \\
\text { industries }\end{array}$ & $\begin{array}{c}\text { Tertiary } \\
\text { industries }\end{array}$ & YMK \\
\hline Peking & 0.801 & 1.00 & 1.00 & 1.00 & He'nan & 0.815 & 0.581 & 0.679 & 0.815 \\
\hline Tianjin & 0.702 & 0.952 & 0.871 & 0.952 & Hubei & 0.594 & 0.538 & 0.57 & 0.594 \\
\hline Hebei & 1.00 & 0.506 & 0.683 & 1.00 & Hunan & 0.691 & 0.605 & 0.771 & 0.771 \\
\hline Shanxi & 0.404 & 0.669 & 0.559 & 0.669 & Guangdong & 1.00 & 1.00 & 1.00 & 1.00 \\
\hline Inner Mongolia & 0.705 & 1.00 & 0.691 & 1.00 & Guangxi & 1.00 & 0.535 & 0.524 & 1.00 \\
\hline Liaoning & 1.00 & 0.804 & 0.652 & 1.00 & Chongqing & 0.412 & 0.704 & 0.591 & 0.704 \\
\hline Jilin & 0.943 & 0.806 & 0.662 & 0.943 & Sichuan & 0.88 & 0.515 & 0.539 & 0.88 \\
\hline Heilongjiang & 0.722 & 0.665 & 0.626 & 0.722 & Guizhou & 0.337 & 0.436 & 0.862 & 0.862 \\
\hline Shanghai & 1.00 & 1.00 & 0.774 & 1.00 & Yunnan & 0.616 & 0.534 & 0.655 & 0.655 \\
\hline Jiangsu & 1.00 & 0.822 & 1.00 & 1.00 & Shaanxi & 0.64 & 0.74 & 0.488 & 0.74 \\
\hline Zhejiang & 0.908 & 0.98 & 0.931 & 0.98 & Gansu & 0.467 & 0.462 & 0.715 & 0.715 \\
\hline Anhui & 1.00 & 0.592 & 0.788 & 1.00 & Qinghai & 0.671 & 0.525 & 0.497 & 0.671 \\
\hline Fujian & 0.93 & 0.762 & 0.749 & 0.93 & Ningxia & 0.819 & 0.662 & 0.612 & 0.819 \\
\hline Jiangxi & 0.936 & 0.719 & 0.694 & 0.936 & Xinjiang & 0.883 & 0.798 & 0.511 & 0.883 \\
\hline Shandong & 0.964 & 0.653 & 0.781 & 0.964 & & & & & \\
\hline
\end{tabular}


From Table 5, the YMK-DEA efficient provinces are Beijing, Hebei, Inner Mongolia, Liaoning, Shanghai, Jiangsu, Anhui, Guangdong, and Guangxi. And Guangdong is the only province which scores " 1 " in every industry. Zhejiang and Shandong are also highly efficient, whose scores are 0.98 and 0.964 . We can see from the data that the efficient provinces are mostly in the east area. Of the provinces, Hubei scored only 0.594 in 2009. However, no slackness of carbon emission could be observed through our calculated data, which means Hubei is emitting a large amount of carbon dioxide. So Hubei province should make more effort to improve the technology of reducing the carbon emission. In this way, the efficiency might be improved. Shaanxi is another low scored province because of the extensive use of energy. For China's eight economic regions, it showed the same trend as the case for each industry, i.e., the eastern coastal area is with higher efficiency than the western inland area.

According to the YMK-DEA efficiency, the provinces are divided into three groups as showed in Table.6. Provinces which scored the most for the primary industry were members for the first group. Provinces which are dominated by the secondary and tertiary industries relatively are put into the second and third groups, respectively.

Table 6. Provinces divided as the dominated industry

\begin{tabular}{ll}
\hline Group & Provinces \\
\hline Primary industry dominate & $\begin{array}{l}\text { Hebei, Liaoning, Jilin, Heilongjiang, Shanghai, Jiangsu, Anhui, Jiangxi, } \\
\text { Shandong, He'nan, Hubei, Guangdong, Guangxi, Sichuan, Ningxia, Xinjiang }\end{array}$ \\
Secondary industry dominate & $\begin{array}{l}\text { Tianjin, Beijing, Inner Mongolia, Shanxi, Shanghai, Zhejiang, Guangdong, } \\
\text { Chongqing, Shaanxi }\end{array}$ \\
Tertiary industry dominate & Beijing, Jiangsu, Fujian, hunan, Guangdong, Guizhou, Yunnan, Gansu \\
\hline
\end{tabular}

The provinces in the group "Primary industry dominant" are provinces with the highest efficiency in primary industry of the three industries. However, it doesn't mean that the provinces in this group are more efficient than the other province in the primary industry. The provinces in this group should pay more attention to the other two industries during the industrialization and urbanization of China. The number of "Primary industry dominant" provinces is the largest while the number of "Tertiary industry dominant" provinces is the smallest. Because the tertiary industry is thought to be friendly to the environment, the energy intense and carbon emission intense are the biggest. Accordingly, more efforts should be make to develop the tertiary industry in China. More resources should put and policies should be made to support the development of the tertiary industry in latter years.

\section{Conclusions and Suggestions}

The DEA model for parallel system with independent subsystems as well as the traditional CCR model was employed in this study to measure the efficiency for 29 provinces in mainland China. From the result and analysis for the result, we could roll out the following conclusions:

Generally, the number of YMK-DEA efficient provinces is rather small, which means there are an improvement room for most provinces. It's necessary for those provinces to improve their efficiency. As to each industry, the case is more or less the same, especially for the tertiary industry.

There is a disparity in efficiency among regions. The efficiency of eastern coastal area is obviously higher than that of the western interior area. So, the production efficiency for each province is relevant to the economic development level.

The efficiency for the primary industry is higher than that for the secondary and tertiary industries in average, and the score for the tertiary industry efficiency is the lowest. The tertiary industry is environment friendly and the industrial restructuring in China calls for more invest in the tertiary industry. The tertiary industry usually shows less restrictive of the locations and the resources and the smallest advantage of first-mover

Policy makers should polish environmental regulations to prompt provinces with large potential for carbon emission reductions to improve the efficiency.

According to the findings above, we suggest that: All regions should develop the energy-saving and environment friendly industries. The China's government should pay more attentions on the following issues: strengthening the corporation between regions at different efficiency levels, developing the tertiary industry during the processes of industrialization and urbanization, exploring new energy that emit less greenhouse gases, and reducing the utilization of fossil fuel gradually. 


\section{References}

Ang, B. W. (1999). Is the Energy Intensity a Less Useful Indicator Than the Carbon Factor in the study of Climate Change? Energy Policy, 27(5), 943-946. http://dx.doi.org/10.1016/S0301-4215(99)00084-1

Azomahou, T., \& Van Phu, N. (2001). Economic Growth and $\mathrm{CO}_{2}$ Emissions: a Nonparametric Approach. Working Paper.

Ge, Hong, \& Huang Wei. (2010). Three Network DEA Models for Parallel Systems and Selection in Application. Journal of Systems \& Management, 19(2).

Grossman, G. M., \& Krueger, A. B. (1991). Environmental Impacts of a North American Free Trade Agreement. Working Paper, No.3914, National Bureau of Economic Research.

Grubler, A. (1998). Technology and Global Change. Cambridge University Press, Cambridge, UK.

Guo et al. (1992). Analysis for industries growth factor and character change. Economic Research Journal, (2).

Guo, X. D. (2010). Evaluation of potential reductions in carbon emissions in Chinese provinces based on environmental DEA. Energy Policy.

Liu, Minglei, Zhu, lei, \& Fan, Ying. (2011). Evaluation of Carbon Emission Performance and Estimation of Marginal $\mathrm{CO}_{2}$ Abatement Costs for Provinces of China: A Non-parametric Distance Function Approach. China Soft Science, (3).

National Bureau of Statistics of China. (2010). Chinese Energy Statistics Yearbook 2010. Beijing: China Statistics Press.

National Bureau of Statistics of China. (2010). Chinese Statistics Yearbook 2010. Beijing: China Statistics Press.

Sun, Licheng, \& Zhou, Deyong. (2009). Study on Regional Environmental Performance Based on Non-Radial DEA Model. Statistics \& Information Forum, 24(9).

Xu, Xianxiang, Zhou, Jimei, \& Shu, Yuan. (2007). Estimates of Fixed Capital Stock by Sector and Region in China: 1978-2002. Statistics Research, 24(5).

Yang, Yinsheng, Ma, Benjiang, \& Koike, M. (2000, September). Efficiency-measuring DEA model for production system with k-independent subsystems. Journal of the Operation Research Society of Japan, $43(3)$.

Zaim, O., \& Taskin, F. (2000). Environmental Efficiency in Carbon Dioxide Emissions in the OECD:A Non-parametric Approach. Journal of Environmental Management, 58(2), 95-107. http://dx.doi.org/10.1006/jema.1999.0312

Zhou, P., Ang, B. W., \& Han, J. Y. (2010). Total factor carbon emission performance: A Malmquist index analysis. Energy Economics, 32(1), 194-201. http://dx.doi.org/10.1016/j.eneco.2009.10.003

Zhou, P., Poh, K. L., \& Ang, B. W. (2007). A non-radial DEA approach to measuring environmental performance. European Journal of Operational Research, 178(1), 1-9. http://dx.doi.org/10.1016/j.ejor.2006.04.038 